\title{
Rebecca Harding Davis's Writing of American Women's Changing Structure of Feeling in the Transition Period (1860s-1890s)
}

\author{
Shanshan Li \\ Zijingang Campus, Zhejiang University, 866 Yuhangtang Road, Hangzhou, China \\ lishanshanlisa@163.com
}

Keywords: Structure of feeling, Rebecca Harding Davis, Transition period, Self

\begin{abstract}
The structure of feeling, which is a key term in Raymond Williams's theories of cultural studies, is defined as "social experiences in solution, as distinct from other social semantic formations which have been precipitated and are more evidently and more immediately available”. This concept has been employed as an analytic tool since 1950s and it provides a new perspective to understand and interpret Rebecca Harding Davis's writing of American women in the second half of the nineteenth century. When the Civil War broke out in 1861, the United States had entered a period of transition from agricultural society to industrial society which was marked by dramatic changes in every field of the society. The period after the Civil War was characterized by rapid growth of industrialization, urbanization, transportation reform, and continuous flows of immigrants. These events, the process of which had begun before the war, forever changed people's life. Being raised in a rapidly growing mill town and witnessing at first hand the cruel realities of the Civil War, Rebecca Harding Davis made timely response to the rapidly changing world and shaped her distinctive literature of the mid to late nineteenth century. In her stories about women, Davis seized and recorded American women's changing structure of feeling which was both complex and subtle with a powerful literary voice. In order to realistically present women's changing life and their various new experiences, to express their complicated and subtle emotions and feelings when they face their new role both in family and in public sphere, Davis struggled to find new literary forms and experiment with new ways of articulation.
\end{abstract}

\section{What is Structure of Feeling?}

Structure of feeling is a key term in Raymond Williams's theories of cultural studies and cultural materialism. The concept is first proposed in 1954 in A Preface to Film, and is repeatedly discussed, disputed, refined and redefined over the next two decades. In order to fully grasp this concept, we should at first know how Williams defines "culture". The word [culture] which had indicated a process of training within a more assured society became in the nineteenth century the focus of a deeply significant response to a society in the throes of a radical and painful exchange. The dear of culture, it seems to me, is best studied as a response of this kind; the response of certain men, attached to certain values, in the face of change and the consequences of change.

In Williams's context, the meaning of culture is wholly identified with the processes of change. In his opinion, the industrial revolution of the nineteenth century has transformed England, France and other countries where it takes place, and it has produced a new society in these countries. Williams understands and describes the nineteenth century culture as the response of people with certain values, in the face of change, to a society marked by radical change. "Response" here indicates understanding and action, that is "what we understand we can do". Consciousness and articulations are forms of agency, while description and representation are kinds of moral and political choice.[1] This discourse on culture, in this account, draws together issues of change, value and articulation (response), which Williams also identifies as the specific, and vital preoccupations of his own generation.[1] According to Williams, culture should not be described and analyzed in a past tense, because every element in it is in solution, is being experienced and being felt exactly now in contemporary life.

The structure of feeling is thus coined by Williams with an effort to develop an overarching 
analytic framework for analysis of culture which is ever-changing and which comprises a variety of elements. In Marxism and Literature (1977), the structure of feeling is defined as:

[...] social experiences in solution, as distinct from other social semantic formations which have been precipitated and are more evidently and more immediately available. Not all art, by any means, relates to a contemporary structure of feeling. The effective formations of most actual art relate to already manifest social formations, dominant or residual, and it is primarily to emergent formations (though often in the form of modification or disturbance in older forms) that the structure of feeling, as solution, relates.

The structure of feeling is distinct from other social semantic formations such as "worldview" or "consciousness" which have become "finished products", and it is used especially to describe the new and emergent living experiences and feelings, which are both complex and difficult to perceive, of people living in present. And according to Williams, the structure of feeling is an ever-changing organism, it arises in the process in which people experience life and react to life. This process can be directly and easily observed in the history of a language. In spite of substantial and some decisive continuities in grammar and vocabulary, no generation speaks the same language as its predecessor. There would be additions, deletions, modifications, or changing of the meaning or usage of a specific word in that particular language. For example, in China, on the eve of the Spring Festival, there is a CCTV Spring Festival Gala Evening. Usually, the hosts and the crosstalk actors will include in their talk or conversation "hot words" of the whole year popular with Chinese. In my opinion, these "hot words" are evidence and indications of a new and emergent structure of feeling. Similar changes can be observed in manners, dress, buildings, and other forms of social life. Every generation has its own unique structure of feeling, because people respond in their own way to the unique world they live in.

Williams points out that, the structure of feeling of a society becomes evident in moments of transition, of change, and is especially evident in formal shifts in the practice of art and literature. When change is felt, recognized and and people becomes conscious of it, ready means of articulation could hardly express the new experience, then the structure of feeling is apparent and evident exactly in the dialectical tension between conventional ways of articulation and people's new living experience.

The idea of a structure of feeling can be specifically related to the evidence of forms and conventions - semantic figures-which, in art and literature, are often among the very first indications that such a new structure is forming.

Generally speaking, a structure of feeling becomes manifest in the area of emerging consciousness, in new articulations and representations etc. The structure of feeling is wholly defined in the context of the analysis of changes in a society or culture. The evidence of change, at the level of the structure of feeling, is consistently generated by the comparison between the experience of new feelings or ideas with conventional ways of expression.

Conventions - the means of expression which find tacit consent-are a vital part of this structure of feeling. As the structure changes, new means are perceived and realized, while old means come to appear empty and artificial.

What the the artists and authors always struggle to do is to find new ways to describe new concerns, new interests, new experience of people, and express their new common understanding about them, especially in the face of change from outside.

The theory of the structure of feeling provides a new perspective for the analysis and interpretation of Rebecca Harding Davis's (1831-1910) writing of American women living in the transition period, especially in the second half of the nineteenth century. As a sensitive author, Davis always made efforts to explore and experiment with new literary forms and new ways of expression to record, articulate and present the real life, especially the various new experiences of people of her time. 


\section{Davis's Writing of Women's Ever-Changing Structure of Feeling}

Rebecca Harding Davis has widely been acknowledged as a pioneer realist "who helped shape the development of American literary realism and whose texts are valuable artifacts of nineteenth-century culture" [2]. Living in a dynamic period of intellectual history, Davis made her own contribution to accelerating transition from romanticism to realism and the developing of realism aesthetics. In a career that spanned nearly 50 years, Davis produced over 275 stories, 12 novels, 125 juvenile stories, over 200 identifiable essays, and perhaps an equal number of unsigned essays [3]. Davis's masterpiece "Life in the Iron-Mills", published in Atlantic Monthly in April 1861, precisely on the eve of the Civil War, is generally regarded as a forerunner or early example of American literary realism[4], and as representing the first step in American literature's transition from romanticism to realism[5]. When the Civil War broke out in 1861, the United States had entered a period of transition from agricultural civilization to industrial civilization which was marked by dramatic changes in every field of the society. The period after the Civil War was characterized by rapid growth of industrialization, urbanization, transportation reform, and continuous flows of immigrants. These events, the process of which had begun before the war, forever changed people's life. Being raised in a rapidly growing mill town (Wheeling) and witnessing at first hand the cruel realities of the Civil War, Rebecca Harding Davis made timely response to the rapidly changing world by telling "story of to-day", ${ }^{5}$ and shaped her distinctive literature of the mid to late nineteenth century. In her large body of works, we see how people lived in the nineteenth century, particularly what changes were brought to American people by big movements, such as industrialization, the Civil War, the immigrant flows etc, and how people reacted to these changes.

Women's life is a major concern of Davis's works. During the sixties, Davis focused on various subversive elements within sentimentalism to exposed the pain of an ethos that repressed women's independence, individuality and creativity; During the seventies, women began to come out of the "women's sphere", and exert some influence in their career and in the public, but their professional, sexual, and political energies were seen as serious threats to bourgeois culture [6]. In order to make a living independently, they paid the price by giving up a lot, even their femininity; In the last two decades of the nineteenth century, although many new women had been quite successful in their career, some of whom even gained respect and reputation, and had enhanced their social position, people still expected them to play their traditional role as a wife or a mother, and usually neglected their inner world and spiritual needs.

In the following part, the author of this paper chooses three representative woman characters in Davis's stories: Hester Manning from “The Wife’s Story”(1864), Jenny Derby from “Earthen Pitchers"(1874) and Mrs. Palmer (Anne) from “Anne” (1889), to illustrate that, as a sensitive writer with keen insight, Davis timely seized and recorded American women's ever-changing and dynamic structure of feeling in the second half of the nineteenth century which was both complex and subtle in her works.

\subsection{Hester Manning's Adventure}

Compared with "angels in the house", the traditional female characters in American literature, Hester Manning, the heroine of "The Wife's Story", is a "New Woman" in a broad sense. Hester Manning told the story in the first person narration. From the beginning of the story, we know that Hester had married Doctor Manning one and a half years ago. When Hester knew that her husband's investment had failed, the "terror and temptation which had beset" her married life from the beginning was taking a "definite shape and hold."

I had a unquiet brain, of moderate power, perhaps, but which had been forced and harried and dragged into exertion every moment of my life, according to the custom with women in the States where I came. Every meanest hint of a talent in me had been nursed, every taste purged, by the rules of my father's clique of friends. The chance of this was all over, - had been escaping since my marriage-day. ${ }^{6}$

Different from her Western-born husband whom she thought boorish and reckless, Hester was 
born in New England, and was brought up with the motto that "The only object in life is to grow." ? The name "Hester" naturally reminds us of Hester Prynne in The Scarlet Letter. Davis did not name the character accidentally. Two names are in intertextuality. Hester Manning shares Hester Prynne's desires and passion, and is equally thirsty for freedom and a happy life. Hester thought that she had talents for art, and was sure that she had been born with some holy mission given by the God to fulfill. But unfortunately, she felt that the household duties were wasting her talents and exhausting her energy. After Hester became more and more estranged with her husband and totally desperate with her married life, she was determined to escape from the house and make a living by singing opera. She was so eager to be free and independent, to show her talents and to tap her potentials, to satisfy her hungry brain and stimulated tastes ${ }^{8}$. Of course, it was no easy decision. She calculated what it would cost her to lose her husband and escape from the family. She knew that if she entered that gate, there would be no returning. There arose sharp conflict and anguish in Hester's mind and heart. In fact, she craved for affection and love from others, especially from her husband, but she was frustrated and disappointed from time to time. Davis meticulously shows the tortured inner world of the heroine. The wrench in Hester's heart and brain became intense and unbearable when she saw her sallow face in the mirror and felt a fierce disgust with herself. She could no longer bear the the ignorance of the actual brain- and soul-wants. Finally she decided to go on the first day when the whole family moved to Newport where they had planned a new life. Hester firmly believed that there were more than one way in life. And she wanted to find the gate into another world.

Hester cooperated with M. Vaux, the theatre manager who was vulgar, but who symbolized fame, achievements, freedom, career and self-expression, and acted in an opera created by herself. The opera and the whole performance turned out to be a total failure. What was worse was that Doctor Manning died of a heart attack as a result. Hester, desperate and hopeless, went to the harbor and meant to drown herself.

When the readers think that Hester paid the price by drowning herself and the story comes to an end, they surprisingly find that, it was all in the fantasies of a brain-fever dream, that Hester's escape and Doctor Manning's death never happened. Finally, Hester woke from the nightmare illness "thirst for love, and to love" and lived a very satisfied life with her husband and children. It's a happy ending which is consistent with the readers's attitude and values of Davis's time. In my opinion, what Davis indicates in Hester's adventure to escape is that for a woman, to be free and independent on her own capacity and talents in 1860s was just a brain-fever dream. If she did try to transgress the bounds of the traditional values and disciplines, she would pay the price by acting as an outcast or even as a death causer. What is significant about the "The Wife's Story" is that, Davis vividly shows the anguish of women in the 1860s. Women of the 60s had gradually realized their power and potential, they craved for love and affection, they desired to be free and independent, they wanted to satisfy their brain- and soul- wants, but they couldn't, because they were confined and caged in "women's sphere”.

\subsection{Jenny Derby's Loss}

In the seventies, with the advancement of natural science and social science, the changing of economic environment, and the development of female education, women had greatly enhanced the sense of self, gender, and mission, and had plunged into a "larger life" in the society.

Jenny Derby, the heroine of "Earthen Pitcher", is an antecedent of the New Woman in the 1870s. As the daughter of a radical reformer, Jenny had traveled around in Europe with her father and had a chance to see life. Better educated than average, Jenny began to live alone at a very early age, and made a living by writing articles, book notices, as well as arranging a woman's column. Jenny was also the hostess of "Saturday Evening", a very well-known social gathering. But unlike the charming and noble hostess of a upper-class salon, Jenny was only a poor girl with unformed figure and manners of a fifteen-year-old girl, who could only provide low qualified tea and toast for her guests.

I do it because it pays me, you may be sure of that. In town they talk of me as a sharp woman 
pushing into a man's place. People come here and they know me afterward as Jenny Derby: a genial, warm-hearted little thing that need help. And they're all ready to help. You see? ${ }^{9}$

From Jenny's words, we see that she was eager to win a place of her own in the man's world. People from all walks of life did come to the gathering with various purposes, but she could hardly gain respect, fame, and social status as she had expected. "Jenny Derby's not clever", ${ }^{10}$ said Chalkley, one guest of Miss Derby. Actually, the idea that women were emotional, they were not rational and clever was quite popular at that time.[7] "Society never heard of Miss Derby", ' ${ }^{1}$ we see that it was quite difficult for a woman to gain fame and recognition in the society. As for Jenny's writing, Chalkley said, "Same thing over and over; roast, hash, and ragout; you have it again week after week, and, 'pon my word, you dont recognize it." ${ }^{12}$ As a matter of fact, what Chalkley said about Miss Derby represented people's general idea and attitude for female writers in the nineteenth century.

"You must not think of Jenny—of Miss Derby as anything but a very respectable girl. Yes, and a very sweet girl too," he added, but with a quaver as though knowing that he put Society as defiance.

From this detail, we can see that Jenny Derby thought she was successful with her career and she had become somebody and had some influence in the society, but actually it was just her illusion. Through Jenny Derby's experience, we know that the occupational environment was not friendly at all for women in the seventies. Women worked very hard, but they still couldn't live a quite decent and respected life.

What was worse, in order to push herself into the man's world, Jenny had lost her femininity, either passively or willingly. She did not care about her outer appearance. For her, the face does not matter at all. When the gathering was over, and after all the guests left, Jenny

[...] crossed the halls hastily to her own chamber, locked the door, and stirred the clear anthracite fire. Her boots stood on the rug. They were shot, broad and heavily soled; her gloves lay on the table. She took them up, looking at her thick and somewhat stumpy fingers.

When she undressed and saw her hard eyes, thin lips and flat breasts, she said to herself, "forgot that I was a woman", "I'm sharp, and a screw to all the world. " ${ }^{13}$ Only by accident would Jenny realize that she was a woman, and at such moments, she would turn quickly from the glass too happy and ashamed to meet her own eyes.

Men also treated Jenny as "a hearty good fellow" ${ }^{14}$, instead of a young lady. Those who stand with Jenny were wont to talk to her of the strength of her articles, "quite as masculine as if they had been done by a man”.

From Jenny Derby's experience, especially the loss of her femininity, we can see that although, in the seventies, women's situation had improved to some degree, some of them had crossed the boundaries between the private and public sphere, they still faced many challenges and difficulties on their way to independence and success. It was still very hard for them to gain respect, fame, equality and social status as men. "Earthen Pitchers" vividly illustrates a woman's struggle in her career, her dilemma, and loss in the process of searching and pursuing her "Self".

\subsection{Anne’s Dream}

The New Woman reached her stride in the progressive era.[8] In the last two decades of the nineteenth century, women were more engaged in social life, and had further enhanced the sense of self and gender.

Mrs. Palmer in "Anne" led a very orderly life, which was comfortable and secure. She was greatly respected in the neighborhood as a woman of masculine intellect, because after her husband Job died, she had managed the plantation and the house with remarkable energy and success. She had cleared the property of debt, and had invested in Western lands so shrewdly that she and her children became very rich. The children took good care of their dear mama, but they attributed Mrs. Palmer's business success to good luck, instead of their mother's wit.

One day, Mrs. Palmer had a strange dream when she felt asleep out of doors. In the dream, she was Anne again who was only sixteen, and who was beautiful with red cheeks. Young Anne was so alive and throbbing with youth and beauty, and she also had a wonderful voice. In the dream, Anne 
also saw her lover George Forbes and Theresa, whom George married just because she had money. When Anne thought about this, there arose a sharp wrench at her heart. George was a such a magic name for Mrs. Palmer (Anne), that when she called this name, she felt the blood stop in her veins, and she trembled even in her sleep.

When Mrs. Palmer woke from her dream, she was excited to share the dream with her daughter Susan, but the daughter who was busy with sewing, paid no attention to her poor dear mother. This incidence shows that the children neglected their mother's spiritual needs and wants. In their mind, if a Palmer had a good peach farm, a comfortable house, and half a dozen servants to worry, his lines of life were already full and he would not be bothered by other things such as literature or art. So they could not understand why their mother would listen to a hand-organ with tears in her eyes, or would go all the way up to Philadelphia to hear an Italian Stroller with a strange name. Just as Mr. Palmer's name "Job” indicated, the Palmers were all very practical persons who would pay little attention to the spiritual needs.

Even Mrs. Palmer thought it was not decent for her, a middle-aged respectable woman to have such a dream and it was foolish to tell her children about it. But, from then on, Mrs. Palmer could no longer shake off the impression that she was young and beautiful and in love again. When she was alone and saw herself in the mirror, although she saw a stout woman of fifty with grizzled hair and a big nose and yellow cheeks, she was sure that the eyes that she met in the mirror were Anne's. And she found that young Anne, who was passionate and alive, and whom she thought dead long ago, was not dead. Then she was determined to escape from the house. She had done her full duty to her husband, children and property, now, she was to begin somewhere else to live out her own life. She had the chance for the few years left for music and art and the companionship of thinkers and scholars. These things had been so long forbidden to her.

Mrs. Palmer escaped by train, which was the symbol of industrial revolution and "progress". On the train, she happened to meet Mrs. Ames, a famous philanthropist and feminist movement leader, Corvill, a great figure-painter, and George Forbes, whom Anne loved deeply and now a famous poet. Just when Mrs. Palmer thought that she had come into the company of the Immortals, she was so disappointed to find that these three persons were mere hucksters of art and humanity, and George was nothing but a disagreeable, under-bred shop-man of literature, they did not belong to the high pure level on which stood great interpreters of the truth ${ }^{15}$.

Mrs. Palmer's escape failed both because of a train accident, and her painful realization that there was such a great gulf between her dream and the reality. She was brought by her son back to her safe and warm house. At the end of the story, Mrs. Palmer resumed to live a quiet, luxurious and "happy" life, being petted like a baby by all of the Palmers.

Yet sometimes in the midst of all this comfort and sunshine a chance note of music or the sound of the restless wind will bring an expression into her eyes which her children do not understand, at such times, Mrs. Palmer will say to herself, "Poor Anne!” as of somebody she once knew that is dead.

Is she dead? she feebly wonders; and if she is dead here, will she ever live again? ${ }^{16}$

The end of the story is meaningful and thought-provoking. There are four "she" in the last sentence, but they refer to different names, if we replace "she" with the names they represent, the sentence should be: Is Anne dead? Mrs. Palmer feebly wonders; and if Anne is dead here, will Anne ever live again? Anne and Mrs. Palmer represent two different "self" of one person. "Anne" represents freedom, passion, desire and liveliness, and is oppressed by a variety of social norms and traditional values and is confined in Mrs. Palmer's body and her duties to the family. Only by accident would "Anne" reveal its existence. And "she" (Anne) here also represents an average American woman in the nineteenth century. Mrs. Palmer's experience was shared by most American women living in that era. Although women had transgressed the lines of their family and were engaged more in social life, and perhaps they even won fame and respect from others by displaying their capacity and intelligence, what people expected from them was still the traditional role of a wife and mother. People seldom paid attention to their spiritual world and soul wants.

What does a woman truly want? Under what circumstances could we say that a woman has 
realized her true "self”? Women today are still asking these questions and trying to find answers.

\section{Conclusion}

According to Raymond Williams, each generation has its unique structure of feeling, because people respond in their own way to the unique world they live in. As a sensitive writer, Davis timely seized American women's ever-changing structure of feeling in the transition period which was both complex and subtle. In her stories, we see how women lived in the second half of the nineteenth century, we see women's dilemma, struggle, courage, anguish, conflict, as well as the enhancement of their sense of gender and self, their progress in the way to independence. Davis's works are like living fossils which preserve the living memories of that particular era. From the perspective of structure of feeling, we get a better understanding about Davis's stories of "to-day". With literary realism, Davis truthfully and authentically presents women's changing life, especially their various new experiences, their complicated and subtle emotions and feelings when they face their new role both in family and in public sphere.

R. Williams, The Idea of Culture, in Essays in Criticism, pp. 239-266, 1953.

R. Williams, Structure of Feeling, in Marxism and Literature, Oxford: Oxford Press, pp. 133-134, 1977.

Ibid., p. 133.

R. Williams, M. Orrom, A Preface to Film, London: Film Drama, p. 22, 1954

"story of to-day", is the title of Davis's first novel Margret Howth: A Story of Today, in which Davis proclaims her literary principle: to realistically write about people in reality and their life in the living present.

R. H. Davis, The Wife's Story, in Life in the Iron Mills and Other Stories, ed., T. Olsen, New York: The Feminist Press, p. 181, 1985

Ibid., p. 181. This is also Margret Fuller's motto.

Ibid., p. 178 .

R. H. Davis, Earthen Pitchers, in A Rebecca Harding Davis Reader, ed., J. Pfaelzer, Pittsburgh: University of Pittsburgh Press, p. $222,1995$.

Ibid., p. 217.

Ibid., p. 215.

Ibid., p. 217.

Ibid.

Ibid., p. 225.

R. H. Davis, Anne, in A Rebecca Harding Davis Reader, ed., J. Pfaelzer, Pittsburgh: University of Pittsburgh Press, p. 336, 1995.

Ibid., p. 339.

\section{References}

[1] S. S. Matthews, Change and Theory in Raymond Williams's Structure of Feeling, Literary and Culture Studies, vol. 10, no. 2, pp. 179-194, 2001.

[2] J. A. Rose, Rebecca Harding Davis, New York: Twayne Publishers, p. xi, 1993.

[3] J. Pfaelzer, A Rebecca Harding Davis Reader, Pittsburgh: University of Pittsburgh Press, p. xv, 1995.

[4] W. Hesford, Literary Contexts of "Life in the Iron-Mills", American Literature: A Journal of Literary History, Criticism, and Bibliography, vol. 49, no.1, pp. 70-85, 1977.

[5] P. B. Harper, Fiction and Reform II. The Columbia History of the American Novel, ed., E. Elliot, Beijing: Foreign Language Teaching and research, pp. 216-239, 2012.

[6] J. Pfaelzer, Parlor Radical: Rebecca Harding Davis and the Origins of American Social Realism, Pittsburgh: University of Pittsburgh Press, p. 12, 1996.

[7] B. S. Deckard, The Women's Movement, Political, Socioeconomic, and Psychological Issues, New York: Harper \& Row Publishers, p. 3, 1983.

[8] N. Woloch, Women and the American Experience, 2nd ed., New York: McGraw-Hill, p. 269, 1994. 